\title{
Studi Perencanaan Upgrade Transmisi Tegangan Tinggi 150 kV Perak-Ujung Menggunakan Konduktor HTLS (High Temeprature-Low Sag)
}

\author{
(Study of High Voltage Transmission 150 kV Perak-Ujung Upgrade Planning Using HTLS \\ (HighTemperature-Low Sag) Conductor)
}

\author{
Rahmad Yusuf Desprianto, Suprihadi Prasetyono, Dedy Kurnia Setiawan \\ Jurusan Teknik Elektro, Fakultas Teknik, Universitas Jember (UNEJ) \\ Jln. Kalimantan 37, Jember 68121 \\ E-mail: depri.ryd@gmail.com
}

\begin{abstract}
Abstrak
Saluran transmisi udara $150 \mathrm{kV}$ pada umumnya menggunakan konduktor ACSR (Alumunium Conductor Steel Reinfoiced) yang mempunyai titik kerja suhu yang terbatas. Saluran transmisi udara akan mengalami titik jenuh seiring meningkatnya kebutuhan listrik. Dengan menyempitnya lahan dan masalah investasi maka saluran yang telah ada perlu dioptimalkan dengan melakukan reconductoring menggunakan konduktor HTLS (High Temperature Low Sag). Konduktor HTLS mempunyai titik kerja suhu yang tinggi dibandingkan konduktor ACSR. Penelitian ini bertujuan untuk meningkatkan kapasitas hantar arus serta untuk memenuhi kehandalan N-1 dari saluran transimsi udara dengan memilih konduktor jenis HTLS yang meliputi ACCC, ACCR dan TACSR yang sesuai dengan struktur jaringan transmisi. Dengan menggunakan metode keseimbangan panas dalam menghitung ampacity dan metode cartenary dalam menghitung andongan dan tegangan tarik maka akan diketahui konduktor yang sesuai dengan struktur yang telah ada. Dari hasil penelitian menunjukkan konduktor ACCC jauh lebih handal dengan mampu menaikkan kapasitas hantar arus hingga 96,3\% sedangkan ACCR sebesar 83,9 \% dan TACSR sebesar 40,7\%. Dan andongan maksimal ACCC sebesar 4,692 m, ACCR sebesar 6,550 $\mathrm{m}$ dan TACSR sebesar $8,076 \mathrm{~m}$ dengan tegangan tarik yang dibutuhkan pada andongan maksimal berturut-turut sebesar 12,825 kN; $9,086 \mathrm{kN}$ dan $8,119 \mathrm{kN}$.
\end{abstract}

Kata Kunci: konduktor HTLS, reconductoring, transmisi udara.

\section{Abstract}

The air transmission channel $150 \mathrm{kV}$ in general using the ACSR (Aluminum Conductor Steel Reinfoiced) conductor which have a limited temperature working point. The air transmission channel will have a saturated point over rising electricity needs. With narrow land and investment issues then existing channels need to be optimized by doing reconductoring using HTLS (High Temperature-Low Sag) conductor. HTLS conductor has a working point to high temperature compared to the ACSR conductor. This research aims to increase the capacity of ampacity and to fulfill the N-1 reliability of the air transmission channel by selecting type of HTLS conductors which includes the ACCC, ACCR and TACSR that accordance with the structure of transmission network. By using the heat balance method in calculating the ampacity and cartenary method in calculating the sagging and tension then will be known which is in accordance with the existing structure. From the results of research showed the ACCC conductor far more reliable by being able to raise the current capacity until 96,3\% where as ACCR of 83,9\% and TCSR of 40,7\%. And the ACCC maximum sagging of 4,692 m, ACCR of 6,550 $\mathrm{m}$ and TACSR of 8,076 $\mathrm{m}$ by tension needed on the maximum sagging in a row of 12,825 $\mathrm{kN} ; 9,086 \mathrm{kN}$ and 8,119 $\mathrm{kN}$.

Keywords: air transmission, HTLS conductor , reconductoring.

\section{PENDAHULUAN}

Kebutuhan listrik semakin hari semakin bertambah mengingat standar kehidupan manusia yang meningkat. Kehidupan saat ini tidak terlepas dari peranan teknologi yang sumber utama dari teknologi tersebut adalah listrik. Listrik mempunyai peranan yang konvesional sehingga harus adanya keseimbangan antara beban yang ditanggung dengan listrik yang dibutuhkan. Untuk mengimbangi meningkatnya kebutuhan listrik tersebut, usaha atas perencanaan dan pengembangan sistem listrik yang ada harus diupayakan [1].

Reconductoring pada saluran transmisi udara merupakan hal yang mungkin untuk dilakukan pada saat ini, mengingat lahan yang mulai menyempit akibat pengembangan wilayah kota. Reconductoring juga bertujuan untuk meningkatkan kehandalan dalam penyaluran transmisi udara. Hal ini terjadi pada saluran transmisi listrik $150 \mathrm{kV}$ Perak-Ujung Surabaya. Selain kawasan padat penduduk dan kawasan industri, kawasan ini merupakan objek vital yaitu kawasan komando TNI AL bagian timur (LANTAMAL V) sehingga suplai akan daya listrik harus selalu terpenuhi. Selain itu juga saluran transmisi Perak-Ujung merupakan salah satu saluran transmisi yang menghubungkan ke Pulau Madura sehingga diperlukan kehandalan dalam sistem transmisi listrik. Pada tahun 2015 I nominal rata-rata transmisi PerakUjung telah mencapai $77,82 \%$ dari kapasitas yang tersedia [2]. Akibatnya jika terjadi gangguan pada salah satu saluran transmisi maka saluran yang lain tidak dapat menopang 
beban manuver dari saluran yang mengalami gangguan atau lebih dikenal dengan keandalan N-1. Dengan demikian pemadaman bergilir di Pulau Madura menjadi tidak terelakan. Kehandalan sistem ini sudah tidak memenuhi kriteria. Pada saluran transmisi yang tidak memenuhi kehandalan N-1 akan dilakasanakan reconductoring dan uprating [3].

Saluran transmisi udara umumnya menggunakan konduktor jenis ACSR (Alumunium Conductor Steel Reinforced) yang memiliki batas temperatur kerja yang diizinkan sebesar $90^{\circ} \mathrm{C}$ [4]. Konduktor ini mempunyai sifat tahan panas yang berbatas walaupun konduktivitas listriknya tinggi, karena menggunakan bahan aluminium jenis EC grade sehingga tidak dapat memberikan peningkatan kemampuan hantar arus [5]. Konduktor jenis ini dapat beroperasi pada pembebanan harian pada suhu $75^{\circ} \mathrm{C}$. Dengan keterbatasan yang dimiliki oleh konduktor konvensional tersebut memungkinkan penggantian konduktor yang sifatnya mempunyai ketahanan panas yang jauh lebih baik sehingga menghasilkan kapasitas hantar arus yang lebih besar.

Pada saat ini telah dikembangkan beberapa konduktor yang mempunyai keunggulan dibandingkan dengan konduktor yang konvensional atau yang biasa dikenal dengan konduktor High Temperature Low Sag (HTLS). Konduktor HTLS ini mempunyai banyak variasi yang dikembangkan, dimana konduktor jenis ini mempunyai kemampuan lebih baik dibandingkan konduktor konvensional. Sehingga dengan ini dimaksudkan agar dapat menyalurkan daya secara maksimal. Dalam saluran transmisi udara, kawat penghantar harus dirancang sedemikian rupa agar jaringan transmisi mempunyai unjuk kerja yang baik secara mekanis dan elektrik.

Penelitian mengenai upgrade saluran transmisi udara $150 \mathrm{kV}$ sebelumnya telah dilakukan yaitu mengenai Evaluasi Pengaruh Faktor Eksternal Terhadap Mekanisme Kinerja Konduktor ACCC dan ACSR [5]. Penelitian yang sebelumnya yaitu membandingkan kinerja dari konduktor HTLS dengan konduktor konvensional. Namun tidak membandingkan unjuk kerja antara konduktor HTLS. Dengan hal ini penelitian ini bertujuan mengkaji konduktor HTLS yang jauh lebih handal dalam penyaluran transmisi daya listrik. Sehingga dapat menghasilkan proses penyaluran energi listrik yang lebih efektif dan efisien khususnya pada saluran transmisi udara $150 \mathrm{kV}$ PerakUjung.

\section{TINJAUAN PUSTAKA}

\section{Konduktor HTLS}

Konduktor HTLS merupakan teknologi yang dikembangkan untuk memenuhi kebutuhan daya listrik. Konduktor jenis ini mempunyai suhu yang sangat tinggi apabila dibandingkan dengan konduktor yang konvesional. Sehingga dengan mempunyai titik suhu yang tinggi maka kapasitas hantar arus semakin besar. Karena arus yang melalui sebuah konduktor mempunyai batas ambang suhu yang terdapat pada konduktor. Selain itu juga konduktor HTLS ini mempunyai konduktivitas serta kuat tariknya yang lebih baik dibandingkan dengan konduktor yang konvesional.

\section{Perhitungan Temperatur Konduktor}

Perhitungan kemampuan hantar arus konduktor pada saluran transmisi udara memenuhi persamaan keseimbangan panas dimana sebaran panas oleh konveksi ditambah sebaran panas oleh radiasi sama dengan panas dari matahari ditambah oleh rugi-rugi listrik, dirumuskan sebagai berikut[6]:

$$
q_{c}+q_{r}=q_{s}+I^{2} \cdot R\left(T_{a v g}\right)
$$

keterangan :

qc

secara konveksi $(\mathrm{W} / \mathrm{m})$

qr

yang secara radiasi $(\mathrm{W} / \mathrm{m})$

qs

sinar matahari $(\mathrm{W} / \mathrm{m})$

$$
I
$$

$$
R\left(T_{a v g}\right)
$$

temperatur $T_{\text {avg }}(\Omega / \mathrm{m})$

\section{Perhitungan Elektrik Konduktor}

Dengan meningkatnya kemampuan hantar arus maka daya yang akan dihasilkan oleh sakuran transmisi juga ikut meningkat. Karena besar daya berbanding lurus dengan besarnya arus dan tegangan. Untuk mencari daya yang dihasilkan maka diperoleh persamaan

$$
P=\sqrt{3} V \quad x \quad I \cos \varnothing
$$

Keterangan:

$$
\begin{array}{ll}
\mathrm{P} & \text { : Daya (Watt) } \\
\mathrm{V} & \text { : Tegangan (Volt) } \\
\mathrm{I} & \text { : Arus (A) }
\end{array}
$$

Sama halnya dengan daya, rugi-rugi daya berlaku hal yang sama karena semakin besar arus yang dihasilkan maka rugi-rugi daya akan terus meningkat. Selain itu dengan semakin besarnya arus, resistansi konduktor pun akan semakin tinggi, sehingga akan mempengaruhi besarnya rugi-rugi daya yang terjadi.

Berikut merupakan perhitungan rugi-rugi daya pada suatu saluran transmisi listrik.

$$
P L=3 I^{2} x \quad R\left(T_{\text {avg }}\right)
$$

Keterangan :

$$
\begin{array}{lll}
\mathrm{P}_{\mathrm{L}} & : \text { Rugi-rugi Daya (Watt) } \\
R\left(T_{\text {avg }}\right) & : \text { Resistansi AC konduktor pada } \\
\text { temperatur } & T_{\text {avg }} & (\Omega / \mathrm{m}) \\
\quad \mathrm{I} & : \text { Arus per fasa dalam ampere (A) } \\
\text { Perhitungan Mekanik Konduktor } &
\end{array}
$$

Dalam perhitungan mekanik konduktor terdapat tiga kajian yaitu besar andongan, tegangan tarik dan pemuluran terhadap konduktor dari masing-masing jenis konduktor terhadap masing-masing span yaitu dengan menggunakan metode cartenary equation [7]

$$
D=\frac{w l^{2}}{8 H}
$$

Keterangan:

$$
\begin{array}{ll}
\mathrm{D} & \text { : Andongan }(\mathrm{m}) \\
\mathrm{W} & \text { : Berat konduktor }(\mathrm{kg} / \mathrm{m}) \\
\mathrm{H} & \text { : Tegangan Tarik horizontal }(\mathrm{kg}) \\
\mathrm{l} & \text { : Panjang konduktor }(\mathrm{m})
\end{array}
$$




$$
T=H\left(1+\frac{w^{2} l^{2}}{8 H^{2}}\right)
$$

Keterangan:

$$
\begin{array}{ll}
\mathrm{T} & : \text { Tegangan Tarik }(\mathrm{kN}) \\
\mathrm{W} & \text { : Berat konduktor }(\mathrm{kg} / \mathrm{m}) \\
\mathrm{H} & : \text { Tegangan Tarik horizontal }(\mathrm{kg}) \\
\mathrm{l} & \text { : Panjang konduktor }(\mathrm{m})
\end{array}
$$

$$
L=l\left(1+\frac{w^{2} L^{2}}{24 H^{2}}\right)
$$

Keterangan:

$$
\begin{array}{ll}
\mathrm{L} & \text { : Panjang Konduktor Setiap Span }(\mathrm{m}) \\
\mathrm{W} & \text { : Berat konduktor }(\mathrm{kg} / \mathrm{m}) \\
\mathrm{H} & \text { : Tegangan Tarik horizontal }(\mathrm{kg}) \\
\mathrm{l} & \text { : Panjang konduktor }(\mathrm{m})
\end{array}
$$

\section{Metode Rulling Span}

Metode ini digunakan untuk menghitung andongan dan tegangan tarik pada struktur dua dead end yang terdiri atas multi span yang berjarak tak sama[1].

$$
\mathrm{L}_{\mathrm{e}}=\sqrt{\left(\frac{L_{1}{ }^{3}+L_{2}{ }^{3}+L_{3}{ }^{3}+\ldots \ldots \ldots \ldots+L_{n}{ }^{3}}{L_{1}+L_{2}+L_{3}+\ldots \ldots \ldots .+L_{n}}\right)}
$$

Keteranagan :

$$
\text { Le : Span ekivalen (m) }
$$

\section{Pengaruh Faktor Lingkungan}

\section{A. Pengaruh Temperatur}

Pengaruh temperatur menyebabkan pemuaian terhadap konduktor yang menyebabkan pengaruh baik dari kajian elektrik dan mekanik konduktor yang dapat memenuhi persamaan sebagai berikut [8]

$$
L_{\sigma}=L \times\left(1+\epsilon_{\sigma}+\epsilon_{C}\right)
$$

dengan $\epsilon_{\sigma}=\frac{\sigma}{E}=\frac{H}{E A}$

Keterangan:

$$
\begin{array}{ll}
L_{\sigma} & \text { : Panjang konduktor under stress }(\mathrm{m}) \\
L & \text { :Panjang konduktor no stress }(\mathrm{m}) \\
\epsilon_{\sigma} & \text { : elastic strain } \\
\sigma & : \text { Stress }\left(\mathrm{Kg} / \mathrm{mm}^{2}\right) \\
\epsilon_{c} & : \text { Plastic deformation of the cable } \\
E & : \text { Modulus elastis konduktor }(\mathrm{Mpa}) \\
H & : \text { Tegangan tarik pada konduktor }(\mathrm{Kg}) \\
A & : \text { Luas penampang konduktor }\left(\mathrm{mm}^{2}\right)
\end{array}
$$

\section{B. Pengaruh kecepatan angin}

Diasumsikan bahwa angin tidak mengenai keseluruhan pada konduktor. Angin diasumsikan bekerja secara horizontal terhadap permukaan konduktor [9]

$$
W e=\sqrt{(w+w i)^{2}+F^{2}}
$$

Keterangan:

$W e \quad$ : berat konduktor akibat pengaruh angin $(\mathrm{kg} / \mathrm{km})$

W : berat panjang konduktor per meter

wi : berat panjang es per meter

F : gaya horizontal akibat tekanan angin pada saluran $(\mathrm{kg} / \mathrm{km})$.

\section{METODE PENELITIAN}

\section{A. Spesifikasi Konduktor}

Dalam penelitian ini digunakan 3 jenis konduktor HTLS yaitu ACCC, TACSR dan ACCR yang dipilih dengan memperhitungkan konduktor yang hampir sama dengan spesifikasi konduktor existing yaitu konduktor ACSR 340/30 seperti yang ditunjukkan tabel 1. Dengan memperhitungkan baik kajian elektrik maupun kajian mekanik maka akan menjadi suatu rekomendasi bagi pihak terkait sebagai upaya pergantian konduktor (reconductoring) yang sesuai dengan struktur jaringan Perak-Ujung.

\section{B. Flowchart Sistem}

Flowchart sistem ini dimulai memasukkan data awalan sebagai masukan dari perhitungan dengan menggunakan

\begin{tabular}{|c|c|c|c|c|c|}
\hline \multicolumn{2}{|c|}{ Spesifikasi konduktor } & \multicolumn{4}{|c|}{ Jenis Konduktor } \\
\hline \multicolumn{2}{|c|}{ Tipe Konduktor } & $\begin{array}{c}\text { ACSR/AS } \\
340 / 30\end{array}$ & TACSR & ACCC & $\begin{array}{c}\text { ACCR } \\
\text { 636-T16 }\end{array}$ \\
\hline \multirow{3}{*}{$\begin{array}{l}\text { Diameter } \\
(\mathrm{mm})\end{array}$} & Alumunium & 18,00 & 16,56 & 15,8 & 15,9 \\
\hline & Inti (Core) & 6,99 & 8,28 & 7,75 & 9,3 \\
\hline & Total & 24,99 & 24,84 & 23,55 & 25,2 \\
\hline \multirow{3}{*}{$\begin{array}{c}\text { Luas } \\
\text { Penampang } \\
\left(\mathrm{mm}^{2}\right)\end{array}$} & Alumunium & 339,29 & 323 & 361,6 & 322 \\
\hline & Inti (Core) & 29,85 & 41,9 & 47,1 & 52 \\
\hline & Total & 369,14 & 364,9 & 408,7 & 374 \\
\hline \multicolumn{2}{|c|}{ Berat Konduktor (Kg/km) } & 1140 & 1171 & 1083 & 1067 \\
\hline $\begin{array}{l}\text { Resistansi } \\
\text { (ohm } / \mathrm{km})\end{array}$ & $\mathrm{DC} / 20^{\circ} \mathrm{C}$ & 0,0827 & 0,0873 & 0,0771 & 0,0854 \\
\hline \multirow{3}{*}{$\begin{array}{l}\text { Modulus } \\
\text { Elastisitas } \\
(\mathrm{GPa})\end{array}$} & Alumunium & $\begin{array}{c}61,78189 \\
5\end{array}$ & 59,7608 & 54,21 & 55 \\
\hline & Inti (Core) & 162 & 162 & 112,3 & 216 \\
\hline & Total & 69,886 & 71,518 & 60,9 & 77 \\
\hline \multirow{3}{*}{$\begin{array}{l}\text { Koefesien } \\
\text { Muai } \\
\text { Panjang } \\
\left.10^{-6} /{ }^{\circ} \mathrm{C}\right) \\
\end{array}$} & Alumunium & 23 & 23 & 23 & 23 \\
\hline & Inti (Core) & 13 & 13 & 1,61 & 6,3 \\
\hline & Total & 21,126 & 20,382 & 18,5 & 16,6 \\
\hline \multirow{2}{*}{$\begin{array}{c}\text { Temperatur } \\
\text { Operasi } \\
\left({ }^{\circ} \mathrm{C}\right)\end{array}$} & $\begin{array}{c}\text { Operasi } \\
\text { kontinyu }\end{array}$ & 75 & & 180 & 210 \\
\hline & $\begin{array}{c}\text { Batas } \\
\text { Maksimum } \\
\end{array}$ & 90 & 150 & 200 & 240 \\
\hline \multicolumn{2}{|c|}{$\begin{array}{l}\text { Rated Breaking Streanght } \\
(\mathrm{kN})\end{array}$} & 93,92 & 98 & 122,3 & 111,6 \\
\hline
\end{tabular}
perangkat lunak MATLAB. Data awalan berupa spesifikasi konduktor dan kondisi lapangan merupakan masukan untuk menghitung steady state ampacity terhadap masing-masing konduktor. Dalam mencari steady state ampacity, menggunakan metode keseimbangan panas [6]. Setelah didapatkan steady state ampacity, maka akan di beri besar arus awalan yang di set sebesar $30 \mathrm{~A}$. Hal ini dilakukan karena penelitian ini bertujuan untuk menganalisa pengaruh pembebanan arus saluran transmisi terhadap uji secara elektrik yang berupa temperatur konduktor, daya serta rugi-rugi yang dihasilkan dan mekanis yang berupa besarnya andongan, tegangan tarik dan panjang konduktor. Pembebanan arus saluran akan ditambah 20 A sampai mencapai titik kerja suhu maksimal dari masing-masing konduktor. Sehingga dengan mengetahui perubahan arus saluran terhadap uji secara elektrik dan mekanik, memungkinkan untuk mengetahui kehandalan yang akan direkomendasikan sebagai pergantian konduktor (reconductoring) yang sesuai dengan struktur saluran transmisi udara $150 \mathrm{kV}$ Perak-Ujung.

Tabel 1. Spesifikasi Konduktor 


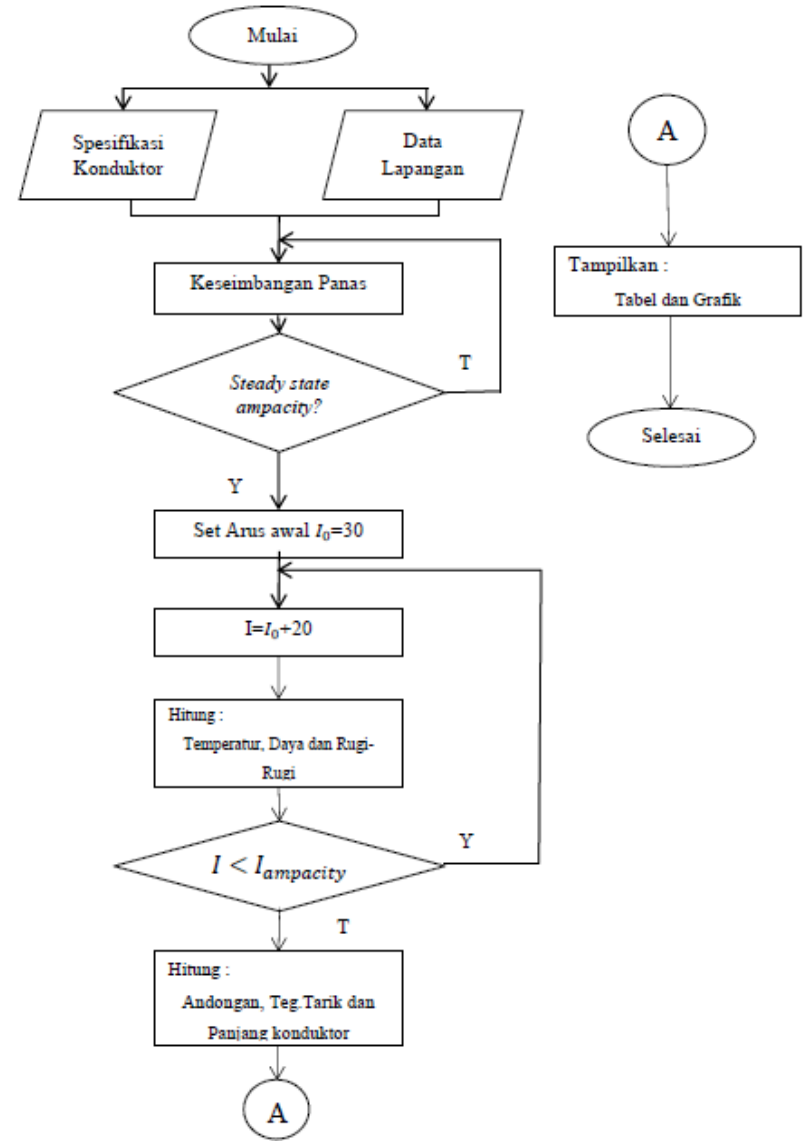

Gambar 1. Flowchart Sistem.

\section{HASIL PENELITIAN}

\section{A. Hasil Pengujian konduktor Existing}

Konduktor yang digunakan pada saat ini pada saluran transmisi Perak-Ujung adalah konduktor jenis ACSR/AS 340/30 yang memeliki titik kerja suhu yang terbatas. Dengan hal ini saluran ini hampir mengalami titik jenuh seiring bertambahnya beban yang pada sepanjang tahun 2015 arus nominalnya hampir mendekati $100 \%$ pada masing-masing sirkit. Pada tabel 2 dapat diketahui saluran telah melampaui batas ideal yang telah di izinkan sebesar $50 \%$. Hal ini menunjukkan saluran transmisi ini tidak memenuhi keandalan N-1. Yang dimaksud dengan keandalan N-1 ini adalah apabila terjadi gangguan disalah satu sirkit maka sirkit yang lainnya dapat menerima beban manuver dari sirkit yang mengalami gangguan. Sehingga dengan hal ini tidak ada terjadinya pengurangan beban terhadap konsumen.

Dari hasil perhitungan dengan menggunakan metode cartenary equation dan keseimbangan panas dapat diketahui kinerja dari segi makanik dan elektrik yang ditunjukkan tabel 3. Jika ditinjau dari tabel 3 arus yang dapat disalurkan pada pembebanan harian sebesar $710 \mathrm{~A}$. Seiring menaiknya arus maka semua kondisi mengalami kenaikan kecuali yang terjadi pada tegangan tarik yang mengalami penurunan. Hal ini disebabkan tegangan tarik maksimal berada pada arus minimal dan kondisi suhu minimal dengan adanya faktor angin[7].

\section{B. Penentu Konduktor HTLS}

Penelitian ini dilakukan pemelihan konduktor dengan pengujian mekanik dan elektrik yang dimaksudkan agar mendapatkan konduktor jenis HTLS yang sesuai dengan kebutuhan disaluran transmisi $150 \mathrm{kV}$ Perak-Ujung.

\section{Pengaruh Arus Terhadap Temperatur Konduktor}

Arus yang mengalir pada konduktor akan menimbulkan rugi-rugi pada konduktor berupa panas. Semakin besar arus yang mengalir akibat arus pembebanan, panas yang dihasilkan oleh konduktor semakin bertambah. Panas konduktor ini tidak hanya dihasilkan oleh rugi-rugi pembebanan arus namun juga dipengaruhi oleh temperatur ambient (lingkungan). Faktor lingkungan sekitar juga mempengaruhi bertambahnya panas terhadap konduktor tersebut. Gambar 2 menunjukkan temperatur meningkat seiring kenaikan terhadap arus. Pada keadaan maksimal ACCC dapat menaikkan arus hingga 1,96 kali pada suhu $196,004^{\circ} \mathrm{C}$ sedangkan konduktor ACCR hantar arus dapat ditingkatkan 1,84 kali pada suhu $237,346{ }^{\circ} \mathrm{C}$ dan TACSR sebesar 1,4 kali pada suhu $147,637^{\circ} \mathrm{C}$ dari keadaan kapasitas hantar arus maksimal konduktor ACSR.

\section{Pengaruh Temperatur Terhadap Andongan Konduktor}

Besar andongan yang dihasilkan akan dipengaruhi oleh temperatur akibat perubahan pembebanan terhadap arus. Garis horizontal yang melintang pada gambar 3 merupakan batas andongan maksimum yang digunakan pada saat ini yaitu sebesar $6,5 \mathrm{~m}$. Gambar 3 Menunjukkan hubungan temperatur terhadap andongan konduktor. Konduktor TACSR melampaui dari batas clearence yang digunakan pada saat ini sehingga konduktor ini tidak dapat digunakan secara maksimal. Sedangkan pada konduktor ACCC menghasilkan andongan yang kecil sebesar 4,692 m. Yang menunjukkan konduktor ACCC lebih handal karena dengan manaikkan kapasitas hantar arus yang lebih besar namun andongan yang dihasilkan jauh lebih kecil dibandingkan dengan konduktor jenis HTLS lainnya.

Tabel 2. Data I nominal Saluran Transmisi Perak-Ujung

\begin{tabular}{ccc}
\hline \multirow{2}{*}{ Bulan } & I nom \% sirkit 1 & I nom \% sirkit 2 \\
& & 76,87 \\
\hline Januari & 76,87 & 78,27 \\
\hline Februari & 77,99 & 76,87 \\
\hline Maret & 76,87 & 79,95 \\
\hline April & 79,66 & 79,66 \\
\hline Mei & 76,87 & 79,95 \\
\hline Juni & 81,05 & 79,95 \\
\hline Juli & 81,05 & 79,66 \\
\hline Agustus & 79,66 & 81,65 \\
\hline September & 81,34 & 84,74 \\
\hline Oktober & 84,41 & 64,30 \\
\hline November & 85,22 & 64,30 \\
\hline Desember & 60,47 &
\end{tabular}


Tabel 3. Perhitungan konduktor existing pada tower 12 span $212,498 \mathrm{~m}$

\begin{tabular}{cccccc}
\hline Kondisi & $\begin{array}{c}\text { Ars } \\
(\mathrm{A})\end{array}$ & $\begin{array}{c}\text { Suhu } \\
\left({ }^{\circ} \mathrm{C}\right)\end{array}$ & $\begin{array}{c}\text { Teg. } \\
\text { Tarik } \\
(\mathrm{kN})\end{array}$ & $\begin{array}{c}\text { Panjang } \\
\text { Kondukt } \\
\text { or }(\mathrm{m})\end{array}$ & $\begin{array}{c}\text { Ando } \\
\text { ngan } \\
(\mathrm{m})\end{array}$ \\
\hline $\begin{array}{c}\text { Pembeban } \\
\text { an Harian }\end{array}$ & 710 & $\begin{array}{c}74.48 \\
0\end{array}$ & $\begin{array}{c}10.86 \\
3\end{array}$ & 212.927 & $\begin{array}{c}5.84 \\
4\end{array}$ \\
\hline $\begin{array}{c}\text { Pembeban } \\
\text { an }\end{array}$ & 810 & $\begin{array}{c}87.56 \\
5\end{array}$ & 9.929 & 213.012 & $\begin{array}{c}6.40 \\
2\end{array}$ \\
\begin{tabular}{c} 
Maksimal \\
\hline
\end{tabular} & & 5 & & & \\
\hline
\end{tabular}

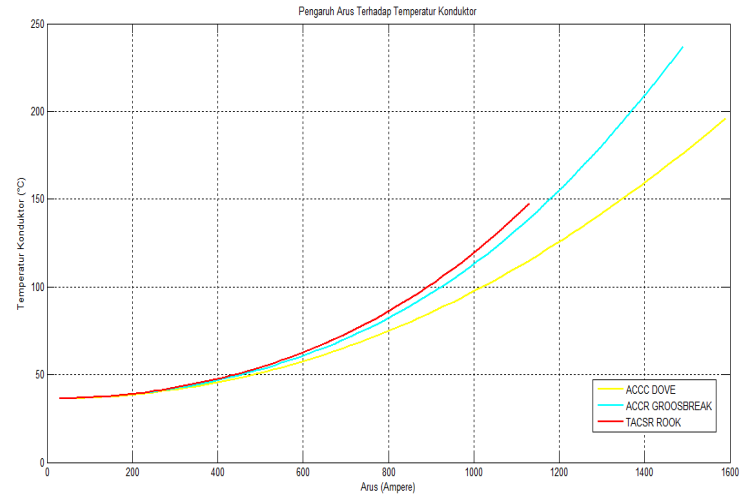

Gambar.2 hubungan arus terhadap temperatur

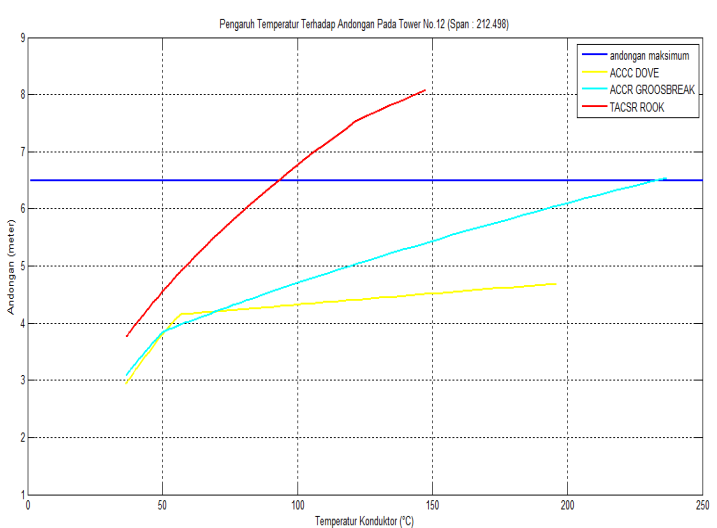

Gambar 3 Hubungan temperatur terhadap andongan

\section{Pengaruh Pembebanan Arus Terhadap Tegangan Tarik Konduktor}

Kenaikan arus berbanding terbalik dengan besaran tegangan tarik. Karena mempunyai spesifikasi yang berbeda pada masing-masing konduktor HTLS maka dengan ini akan diketahui tegangan tarik yang dibutuhkan dari masingmasing konduktor pada setiap span yang terpasang seperti halnya yang ditunjukkan pada gambar. 4. Dalam keadaan pembebanan maksimal konduktor TACSR pada arus maksimal sebesar 1130 A tegangan tarik yang dibutuhkan sebesar 8,119 kN. Saat arus maksimal 1490 A pada konduktor ACCR tegangan tarik yang dibutuhkan sebesar 9,086 kN. Sedangkan pada konduktor ACCC pada saat mencapai arus maksimal 1590 A tegangan tarik yang dibutuhkan 12,825 kN. Tegangan tarik menurun seiring kanaikan arus hal ini terjadi karena tegangan tarik maksimal terjadi pada saat andongan minimum dan suhu minimum. Semakin besar RTS maka semakin tinggi pula tegangan tarik yang dihasilkan. Sesuai dengan data karakteristik konduktor RTS dari masing-masing konduktor berturutturut konduktor ACCC Dove, ACCR Groobreak 636-T16, dan TACSR Rook sebesar 122,3 kN, 111,6 kN, dan 98 kN.

\section{Pengaruh pembebanan Arus Terhadap Panjang Konduktor}

Perbedaan spesifikasi pada konduktor ini khususnya pada koefesien muai panjang menyebabkan pemuluran yang terjadi terhadap masing-masing konduktor berbeda. Konduktor terjadi pemuluran meningkat ketika arus pembebanan meningkat seperti yang ditujukkan pada gambar 5. Jika ditinjau dari gambar 5 hubungan antara arus dan panjang konduktor dengan arus awal yang sama yaitu sebesar 30 A mempunyai panjang konduktor yang berbedabeda dari masing-masing konduktor. Jika ditinjau dari konduktor TACSR Rook pada arus awal panjang konduktor sebesar 212,675 m namun pada saat mencapai arus maksimal panjang konduktor mencapai 213,316 m. Sedangkan pada konduktor ACCR 636-T16 Groosbreak di suhu awal 30 A panjang konduktor sebesar 212,617 m dan pada saat mencapai di titik kerja suhu maksimal pada arus 1490 A panjang konduktor sebesar 213,036 m. Pada konduktor ACCC Dove panjang awal pada arus $30 \mathrm{~A}$ sebesar 212,606 m. Ketika mencapai temperatur maksimal sebesar 1590 A panjang konduktor sebesar 212,774 m. Jika dilihat dari arus yang sama pada 30 A panjang masingmasing konduktor berbeda, jika dilihat konduktor yang mempunyai tegangan tarik semakin tinggi panjang konduktor semakin rendah begitu pun sebaliknya. Dengan hal ini tegangan tarik mempengaruhi panjang konduktor, sehingga dalam pemasangan lebih menguntungkan apabila pemuaiannya tidak terlalu besar. Dan konduktor ACCC Dove memiliki pemuaian yang paling kecil mengingat kapasitas hantar arus yang dihasilkan jauh lebih besar apabila dibandingkan dengan konduktor ACCR 636-T16 Groosbreak dan TACSR Rook.

\section{Kemampuan Penyuplaian Daya dan Rugi Daya yang Dihasilkan}

Upgrade saluran transmisi tegangan tinggi yaitu menambah kapasitas hantar arus pada saluran transmisi udara tersebut. Hal ini dilakukan karena peningkatan kebutuhan beban yang cukup meningkat setiap tahunnya. Dengan meningkatkan kemampuan hantar arus maka penyuplaian daya akan ikut meningkat. Namun seiring meningkatknya pembebanan arus maka rugi-rugi yang dihasilkan akan meningkat pula. Dari hasil perhitungan daya serta rugi daya yang dihasilkan oleh masing-masing konduktor HTLS akan ditujukkan oleh tabel 4. Dalam hasil perhitungan daya yang dihasilkan oleh konduktor ACCC Dove jauh lebih besar dibandingkan dengan ACCR 636T16 Groosbreak TACSR. Pada suhu maksimum daya yang dapat disalurkan oleh konduktor ACCC Dove adalah 413,048 MW lebih besar sekitar 6,7 \% dari konduktor ACCR yang dapat menyuplai daya hingga 387,070 MW dan sebesar 40,7\% dari konduktor TACSR yang dapat menyuplai daya hingga 293,550 MW. Walaupun daya yang dihasilkan konduktor ACCC Dove lebih besar, rugi-rugi daya pada ACCC lebih kecil jika dibandingkan dengan ACCR 636-T16 Groosbreak. Pada suhu maksimal rugi daya yang dihasilkan oleh konduktor ACCC Dove sebesar 0,769279 MW sedangkan pada konduktor ACCR sebesar 
1,071251 MW. Dan pada TACSR rugi-rugi yang dihasilkan sebesar 0,526718 MW.

Jika ditinjau dari rekapitulasi rata-rata beban puncak pada tahun 2015 mencapai 148,142 MW. Dengan mempertimbangkan pembebanan harian menggunakan konduktor ACCC Dove penyuplaian daya dapat ditingkatkan sebesar $164,79 \%$. Sedangkan dengan menggunakan konduktor ACCR 636-T16 Groosbreak penyupalaian daya dapat ditingkatkan hingga 143,75\%. Lebih kecil 21,04 \% dari penyuplaian daya konduktor ACCC Dove.

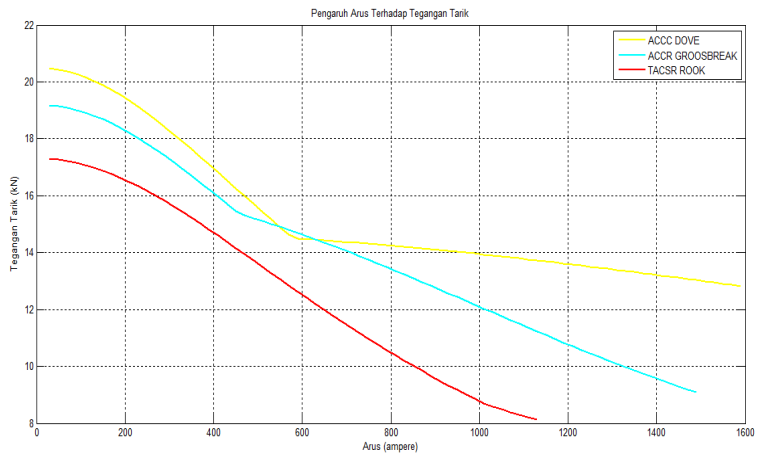

Gambar 4. Hubungan arus terhadap tegangan tarik konduktor

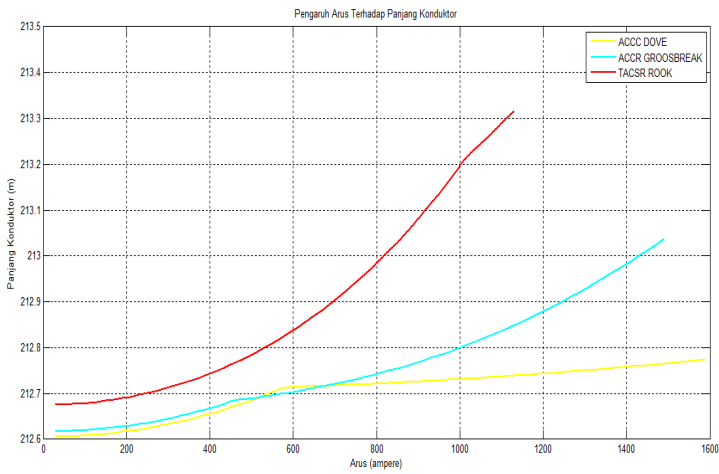

Gambar 5. Hubungan Arus Terhadap Panjang Konduktor

Tabel 4 Perhitungan Daya dan Rugi-Rugi

\begin{tabular}{ccc}
\hline Konduktor & Daya (MW) & Rugi-Rugi Daya (MW) \\
\hline ACCC & 413,048 & 0,769279 \\
\hline ACCR & 387,070 & 1,071251 \\
\hline TACSR & 293,550 & 0,526718 \\
\hline
\end{tabular}

\section{KESIMPULAN}

Dari hasil penelitian yang telah dilakukan, maka dapat diambil beberapa kesimpulan sebagai berikut :

1. Pada keadaan mencapai titik kerja suhu maksimal konduktor HTLS dengan jenis ACCC, ACCR dan TACSR dapat menaikkan kapasitas hantar arus berturut-turut sebesar 1,96 kali ; 1,84 kali dan 1,40 kali lebih besar dari kapasitas hantar arus konduktor konvensional.

2. Konduktor HTLS yang sesuai dengan struktur saluran transmisi $150 \mathrm{kV}$ Perak-Ujung adalah konduktor jenis ACCC dengan mempertimbangkan kenaikan kapasitas hantar arus hingga 1,96 kali dari konduktor konvensional dengan andongan sebesar 4,692 $\mathrm{m}$, tegangan tarik sebesar $12,825 \mathrm{kN}$, pemuluran $0,168 \mathrm{~m}$ dan dapat menyalurkan daya hingga 413,048 MW.

\section{SARAN}

Beberapa saran yang dapat dipertimbangkan untuk pengembangan penelitian selanjutnya adalah:

1. Untuk penelitian lebih lanjut digunakan motede kesimbangan panas transient karena memperhitungkan respon dari perubahan cuaca terhadap pembebanan arus.

2. Diperhitungkan batas kinerja dari konduktor melalui pengujian mekanik dan pengujian elektrik.

\section{DAFTAR PUSTAKA}

[1] Prasetyono, Suprihadi. 2007. Analisis Unjuk Kerja Mekanis Konduktor ACCR Akibat Perubahan Arus Saluran. Universitas Jember. Jurnal Teknik Elektro. Vol. 7(1):18-25.

[2] APP Surabaya. 2015. Rekapitulasi Beban Puncak. Surabaya: APP Surabaya.

[3] PT PLN. 2015. Rencana Usaha Penyediaan Tenaga Listrik (RUPTL) 2015-2024. JAKARTA: PT.PLN.

[4] AAnanda, S. A., Hosea, E., \& Chandra, V. 2006. Pengaruh Perubahan Arus Saluran Terhadap Tegangan Tarik dan Andongan pada Sutet $500 \mathrm{KV}$ di Zona Krian. Universitas Kristen Petra.Jurnal Teknik Elektro. Vol. 6(1):8-14.

[5] Mutaqin, A. Husni. 2013. Evaluasi Pengaruh Faktor Eksternal Terhadap Mekanisme Kinerja Konduktor ACCC dan ACSR pada SUTT $150 \mathrm{kV}$. Universitas Bung Hatta.

[6] Douglass, Dale dkk. 2012. IEEE Standard for Calculating the Current Temperature Relationship of Bare Overhead Conductors. New York: The Institute of Electrical and Electronics, Inc.

[7] Hutauruk, T.S. 1996. Transmisi Daya Listrik. Cetakan IV. Jakarta : Erlangga.

[8] Slegers, James. 2011. Sag Calculations and HighTemperature Conductor Technologies. Ames: IOAW State University.

[9] Das, Debrapiya. 2006. Electrical Power System.Indians Institue of Technology. West Bengal : Indians Institute of Technology. 